\title{
Synthesis and Characterizations of Hydroxyapatite using Precursor Extracted from Chicken Egg Shell Waste
}

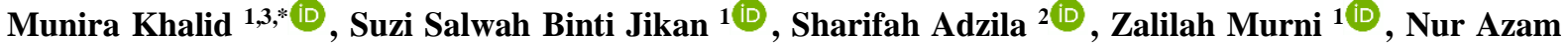 \\ Badarulzaman $^{2}$ (D), Rozainita Rosley ${ }^{1}$ (D), Muhammad Usman Hameed ${ }^{3}$ (D) \\ Faculty of Applied Sciences and Technology, Universiti Tun Hussein Onn Malaysia, Pagoh 84600, Johor, Malaysia \\ 2 Faculty of Mechanical and Manufacturing Engineering, Universiti Tun Hussein Onn Malaysia, 86400 Parit Raja, Johor, \\ Malaysia \\ 3 Women University of Azad Jammu \& Kashmir Bagh 12500, Pakistan \\ * Correspondence: munirakhalidwub@gmail.com (M.K.);
}

Received: 24.08.2021; Revised: 5.10.2021; Accepted: 8.10.2021; Published: 21.10.2021

\begin{abstract}
Hydroxyapatite (HAP) is considered to be one of the most important members of bio-ceramic materials. HAP is widely investigated for the development of biomaterials because of having remarkable chemical similarity to the mineral component, which comprises the bone and hard tissues. The focus of research is to make the whole process eco-friendly, economical, and minimal waste generating. HAP is one of the biomaterials that can be synthesized using naturally occurring wastes such as chicken eggshells, fish scales, etc. The purpose of this research work is to synthesize HAP from Eggshell waste (ESW). The method of preparation used in the current study is the Conventional chemical precipitation method followed by calcination at diverse temperatures. Characterizations of the Eggshell waste extracted from natural HAP powder were carried out using Fourier transforms infrared spectroscopy (FTIR), X-Ray Diffraction Analysis (XRD), energy dispersive X-ray (EDX) spectroscopy, and scanning electron microscopy (SEM). XRD analysis showed the formation of HAP and gave a characteristic apatite peak at 31.8 to 32.5 for $2 \theta$ values. The peaks of FTIR spectrum displays carbonate $\left(\mathrm{CO}_{3}{ }^{2-}\right)$, phosphate $\left(\mathrm{PO}_{4}{ }^{3-}\right)$, and hydroxyl $\left(\mathrm{OH}^{-}\right)$groups in the powder sample, which confirms the synthesis of that HAP. EDX validates the elemental composition of HAP by giving the $\mathrm{Ca} / \mathrm{P}$ ratio, which comes out to be 1.64 for the uncalcined HAP powder. This obtained HAP is the nearest to the pure HAP, which has a Calcium to Phosphate ratio of 1.67. The HAP derived from ESW was synthesized and validated from the results.
\end{abstract}

Keywords: hydroxyapatite; biomaterial; calcination; eggshell.

(c) 2021 by the authors. This article is an open-access article distributed under the terms and conditions of the Creative Commons Attribution (CC BY) license (https://creativecommons.org/licenses/by/4.0/).

\section{Introduction}

HAP is one of the most adaptable biomaterials used for implantation and grafting due to its close similarity to the material with which teeth and bone tissues are made. The chemical formula of HAP is $\mathrm{Ca}_{10}\left(\mathrm{PO}_{4}\right)_{6}(\mathrm{OH})_{2}$ [1-3]. Distinctive features of any material to be considered a biomaterial include bioactive, non-seditious, biocompatible, osteoconductive, harmless, and non-immunogenic [4]. Luckily all these features are present in HAP since HAP resembles with calcium phosphates components of human bone and has proven biocompatibility with these tissues, so it is extensively utilized for biomedical applications [5-8], such as the renovation of skull faults [9], repair of massive bone imperfection, bone tissue engineering [10,11], elimination of heavy metals [12,13] and more importantly in drugs delivery [14,15]. Since HAP has numerous applications in the biomedical field, many methods have been devised to synthesize it, for example, conventional chemical precipitation method, hydrothermal method, 
sol-gel method, mechanochemical method, etc. However, the most commonly employed method for HAP synthesis is the conventional chemical precipitation (CCP) method. Conventional chemical precipitation method is preferably employed because the route of this method is very favorable as no complicated apparatus set up is needed, the working temperature is low, and there is a great possibility of getting the pure product in high percentage $[16,17]$.

In [18], Bardhan performed an XRD analysis to determine the crystalline phase of powdered and sintered HAP. He found the highest intensity peak at 31.79 for the $2 \theta$ value, which is reported as a characteristics apatite peak. G. Pandey in [19] discussed the FTIR results of HAP obtained from eggshell waste. They reported that the spectrum is dominated by the typical $\mathrm{PO}_{4}{ }^{3-}$ bands of crystalline apatite phase characterized by the peaks representing triply degenerate $v_{3}\left(\mathrm{PO}_{4}{ }^{3-}\right)$ asymmetric mode at $1021 \mathrm{~cm}^{-1}$ and $1087 \mathrm{~cm}^{-1}$, non-degenerate stretching mode $v_{1}\left(\mathrm{PO}_{4}{ }^{3-}\right)$ at $962 \mathrm{~cm}^{-1}$ and components of the triplet of $\mathrm{v}_{4}\left(\mathrm{PO}_{4}{ }^{3-}\right)$ bending mode at 560 $\mathrm{cm}^{-1}$ and $470 \mathrm{~cm}^{-1}$.M.R. Saeri et al. in [20] while discussing the scanning electron morphology of HAP synthesized by precipitation method reported that the precipitated HAP particles have small rod-like and some have platy morphology. S.S.Abidi studied HAP powder at different calcination temperatures to get the stoichiometric ratio of 1.667 by using EDX and achieving that at $600^{\circ} \mathrm{C}$. He also reported that above this optimum temperature, the HAP got decomposed to $\mathrm{CaO}[21]$.

The present study aims to synthesize HAP powder utilizing chicken eggshell waste which turns out to be a cost-effective process. CCP method is used, followed by calcination at various temperatures from $600{ }^{\circ} \mathrm{C}$ to $1000{ }^{\circ} \mathrm{C}$. Calcined chicken eggshell waste at $900{ }^{\circ} \mathrm{C}$ was selected as the calcium source for HAP synthesis process. The synthesized HAP powder was analyzed by Fourier transforms infrared spectroscopic technique (FTIR), scanning electron microscopy (SEM), X-Ray Diffraction Analysis (XRD), and energy-dispersive X-ray (EDX) spectroscopy.

\section{Materials and Methods}

The $\mathrm{CaO}$ extracted from eggshell waste was transformed into HAP in phosphate solution using the experimental scheme shown in Figure 1. A chemical precipitation method was used to synthesize HAP.

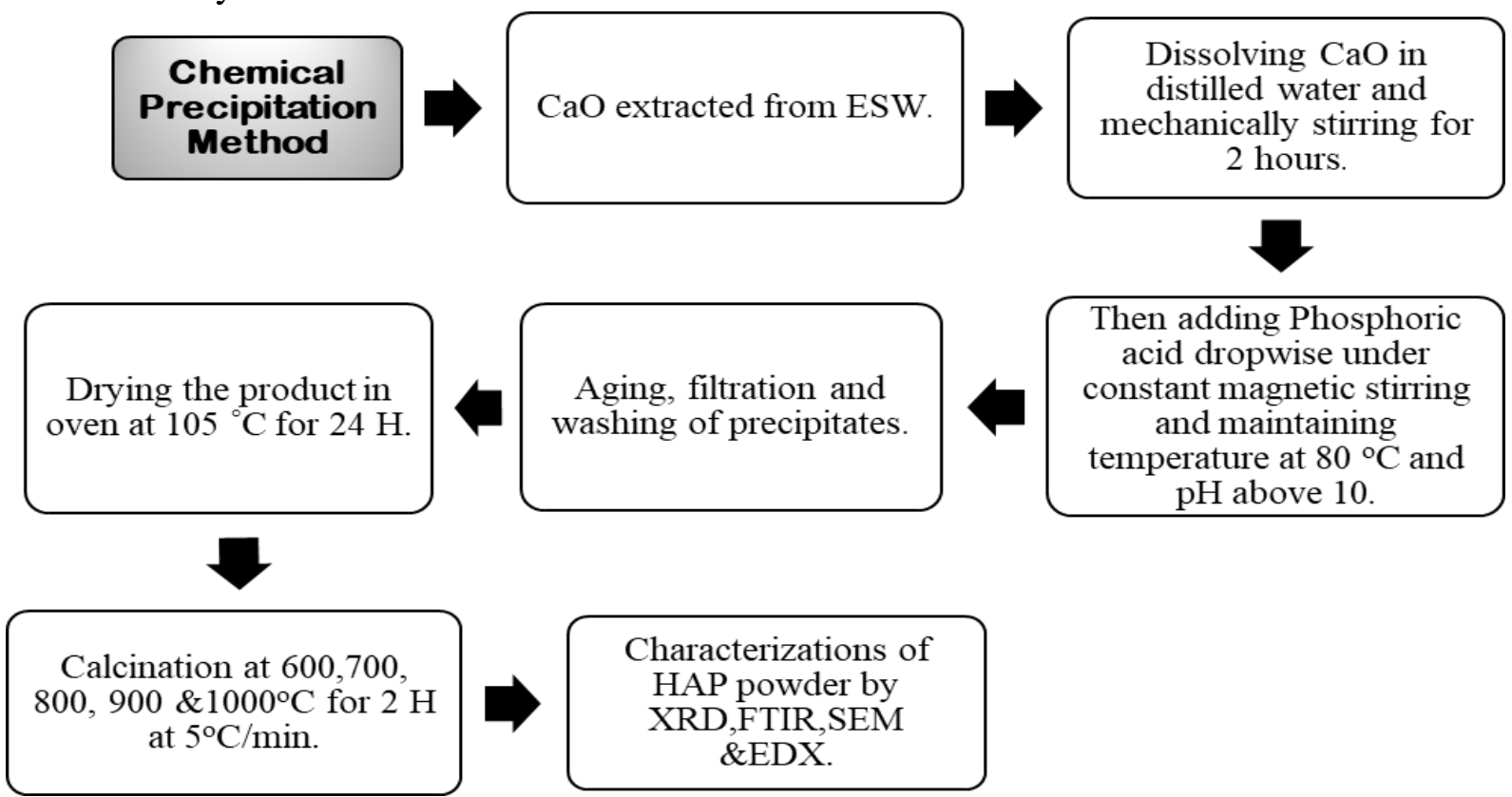

Figure 1. Preparation and characterization of HAP from extracted $\mathrm{CaO}$ via chemical precipitation method. 


\subsection{Synthesis of HAP from extracted CaO via chemical precipitation method.}

In the present work, the precursor used was $\mathrm{CaO}$, extracted by the calcination of chicken eggshell waste at $900^{\circ} \mathrm{C}$ temperature. Orthophosphoric $\operatorname{acid}\left(\mathrm{H}_{3} \mathrm{PO}_{4}\right)$ (Make Merck Millipore) and ammonium hydroxide $\left(\mathrm{NH}_{4} \mathrm{OH}\right)$ (Make Merck Millipore) were used as starting materials. $7.3 \mathrm{~g}$ of $\mathrm{CaO}$ was dissolved in $100 \mathrm{ml}$ distilled water in a beaker. The contents were vigorously stirred at $800 \mathrm{rpm}$ in a mechanical stirrer for $2 \mathrm{H}$, and the temperature was maintained at $40^{\circ} \mathrm{C}$. The assembly was covered to avoid any possible contamination with atmospheric conditions. The $\mathrm{CaO}$ would be converted into $\mathrm{Ca}(\mathrm{OH})_{2}$ according to equation 1 . The phosphoric acid was dropwise added to the $\mathrm{Ca}(\mathrm{OH})_{2}$ at a controlled amount of $1 \mathrm{ml} / \mathrm{min}$. Alongside the addition of acid, the $\mathrm{pH}$ was maintained above 10 with the help of ammonium hydroxide solution, and the temperature was maintained between $40^{\circ} \mathrm{C}-80^{\circ} \mathrm{C}$. The precipitates were left overnight to settle down, and the solution was filtered after $24 \mathrm{H}$. The product was dried in the oven at $105^{\circ} \mathrm{C}$ for $24 \mathrm{H}$ and ground to powdered form in pestle and mortar for further characterization. The preparation of HAP can be understood by the following reactions.

$$
\begin{array}{ll}
\mathrm{CaO}+\mathrm{H}_{2} \mathrm{O} & \rightarrow \mathrm{Ca}(\mathrm{OH})_{2}+\text { Heat } \\
10 \mathrm{Ca}(\mathrm{OH})_{2}+6 \mathrm{H}_{3} \mathrm{PO}_{4} & \rightarrow \mathrm{Ca}{ }_{10}\left(\mathrm{PO}_{4}\right)_{6}(\mathrm{OH})_{2}+18 \mathrm{H}_{2} \mathrm{O}
\end{array}
$$

\subsection{Calcination of synthesized hydroxyapatite.}

The box furnace was used for calcining the prepared HAP in the next step. The range of calcination temperature was chosen between $600^{\circ} \mathrm{C}-1000^{\circ} \mathrm{C}$ with an interval of $100^{\circ} \mathrm{C}$. The HAP powdered samples were titled HAP-600, HAP-700, HAP-800, HAP-900, and HAP-1000, respectively. The box furnace was fixed at $5{ }^{\circ} \mathrm{C} / \mathrm{min}$ for both heatings and cooling with 2 hours holding time. All the prepared samples were allowed to cool inside the box furnace.

\subsection{Characterization of synthesized hydroxyapatite.}

XRD, FTIR, SEM, and EDX were the analytical techniques employed to characterize HAP before and after calcination. The phase identification of crystalline material was elucidated by using XRD.XRD patterns for prepared HAP were recorded in the $2 \theta$ range of $15^{\circ}-70^{\circ}$. The range for FTIR was chosen between $400 \mathrm{~cm}^{-1}-4000 \mathrm{~cm}^{-1}$ for the analysis of functional groups in HAP powder. Scanning Electron Microscope reveals the microstructure of HAP particles. In the same instrument, the weight percentage and atomic percentage of all the elements present in HAP were calculated by using EDX to determine the Calcium to Phosphate ratio. Before analyzing the powdered samples with SEM and EDX they were coated with gold by sputter coater.

\section{Results and Discussion}

\subsection{XRD analysis.}

Figure 2 shows the X-ray diffractogram of the prepared HAP. The scan range for $2 \theta$ was selected between $15^{\circ}$ to $70^{\circ}$. An intense reflection peak at 31.77 of $2 \theta$ values could be clearly seen, which is the representative peak of the apatite.[22, 23]. All peaks belong to HAP phase. The calcination temperature of HAP varied from $600{ }^{\circ} \mathrm{C}$ to $1000{ }^{\circ} \mathrm{C}$. Figure 2 (b) shows the XRD graphs of HAP at diverse temperatures. As it can be clearly seen from the XRD diffractogram, the intensity of the prominent peak, which corresponds to 31.77 , increases as 
the temperature goes from $600{ }^{\circ} \mathrm{C}$ to $1000{ }^{\circ} \mathrm{C}$ and remains as such till $1000{ }^{\circ} \mathrm{C}$, and no decomposition of HAP is being observed. These results agree with the former works and endorse the formation of HAP [24,25].

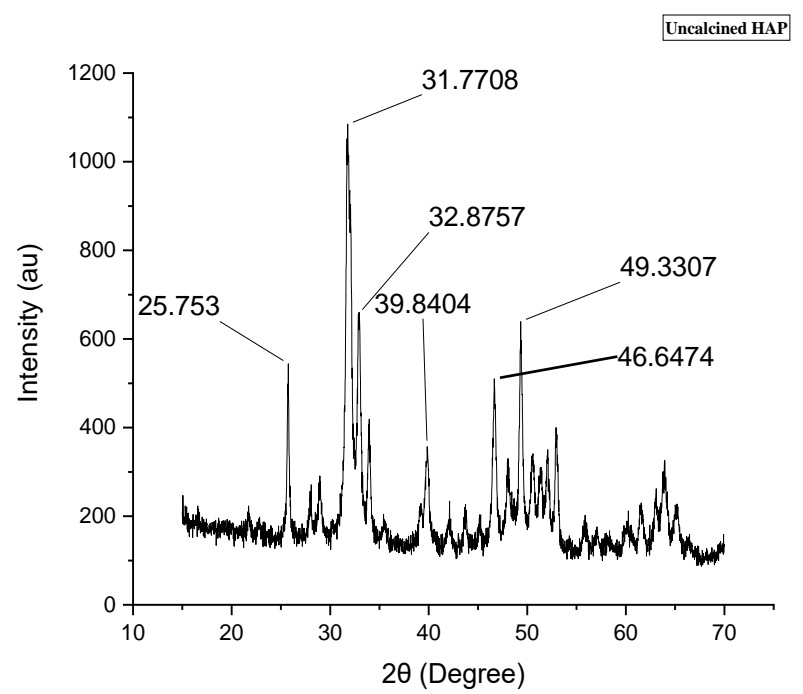

(a)

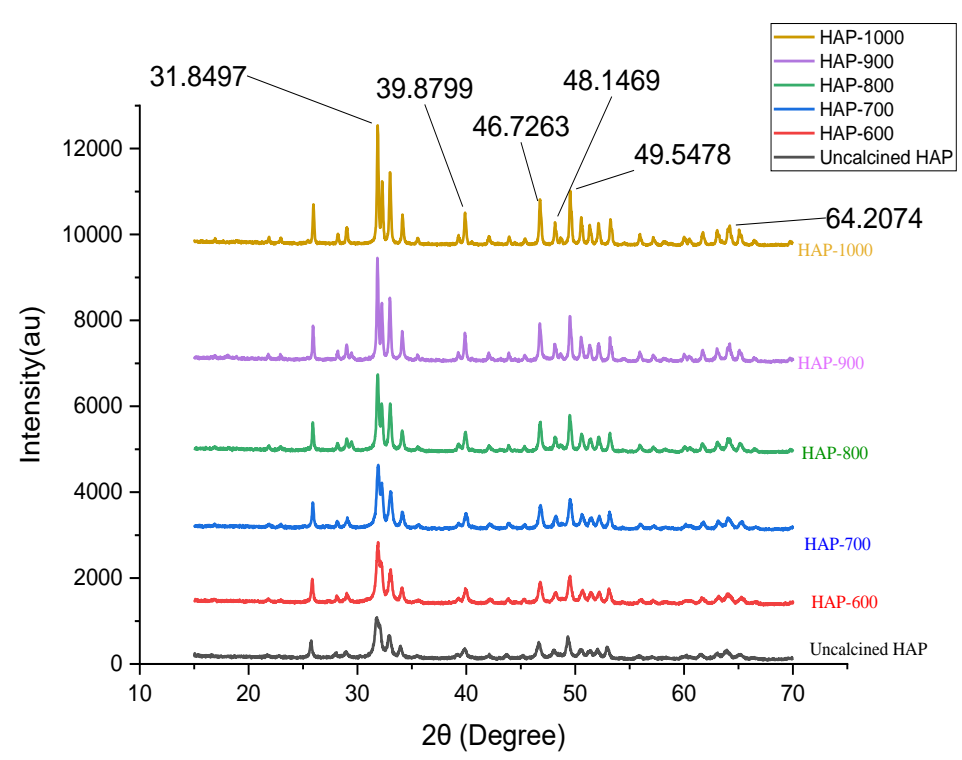

(b)

Figure 2. (a) XRD pattern for Uncalcined HAP; (b) XRD pattern for HAP calcined at various temperatures 600 ${ }^{\circ} \mathrm{C}, 700{ }^{\circ} \mathrm{C}, 800{ }^{\circ} \mathrm{C}, 900{ }^{\circ} \mathrm{C}$, and $1000^{\circ} \mathrm{C}$.

\subsection{FTIR analysis.}

FTIR spectrum for uncalcined and calcined HAP at various temperatures is presented in Figure 3. Infra-red vibration modes of various functional groups of synthesized HAP are presented in Table 1 . The spectra show the phosphate $\left(\mathrm{PO}_{4}{ }^{3-}\right)$, hydroxyl $\left(\mathrm{OH}^{-}\right)$, and carbonate $\left(\mathrm{CO}_{3}{ }^{2-}\right)$ groups. The corresponding peaks of $\mathrm{PO}_{4}{ }^{3-}$ group for $\mathrm{v}_{3}$ and $\mathrm{v}_{4}$ are witnessed at frequencies of 1071-1074 $\mathrm{cm}^{-1}, 601-607 \mathrm{~cm}^{-1}$ and 564-585 $\mathrm{cm}^{-1}$ respectively for both uncalcined and calcined samples. The structural $\mathrm{OH}^{1-}$ vibrational mode is present in uncalcined samples, but it starts disappearing in calcined samples and diminishes at $1000{ }^{\circ} \mathrm{C}$. The bending mode of adsorbed $\mathrm{H}_{2} \mathrm{O}$ is observed in the form of broadband at $1625 \mathrm{~cm}^{-1}$ in uncalcined HAP 
but disappears with increasing calcination temperature. The vibrational mode for $\mathrm{CO}_{3}{ }^{2-}$ is clearly observed at $1426 \mathrm{~cm}^{-1}$, but it can be seen that it has disappeared at elevated temperature in Figure 3 (b). In the present spectra, all the bands present in the reference spectrum can be seen and are found in agreement with previous literature on HAP extraction from eggshell waste [22,24].

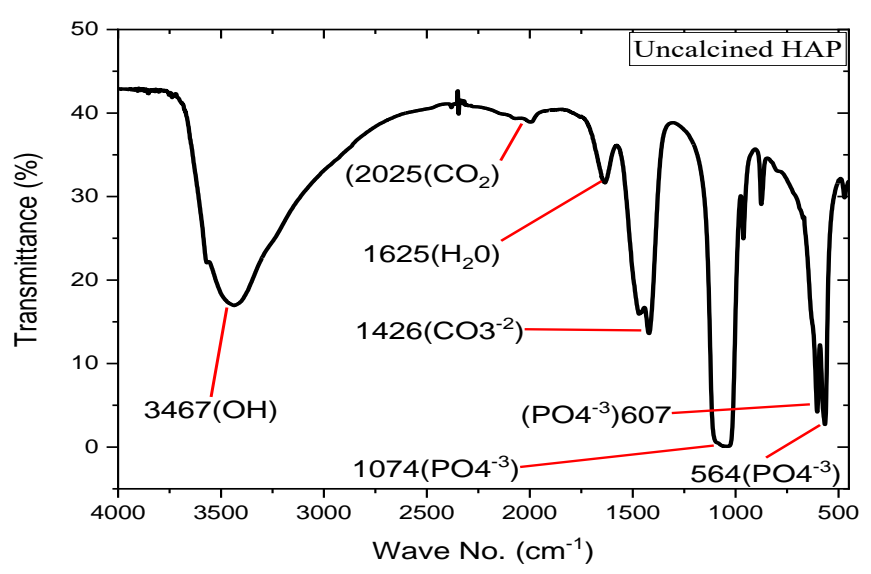

(a)

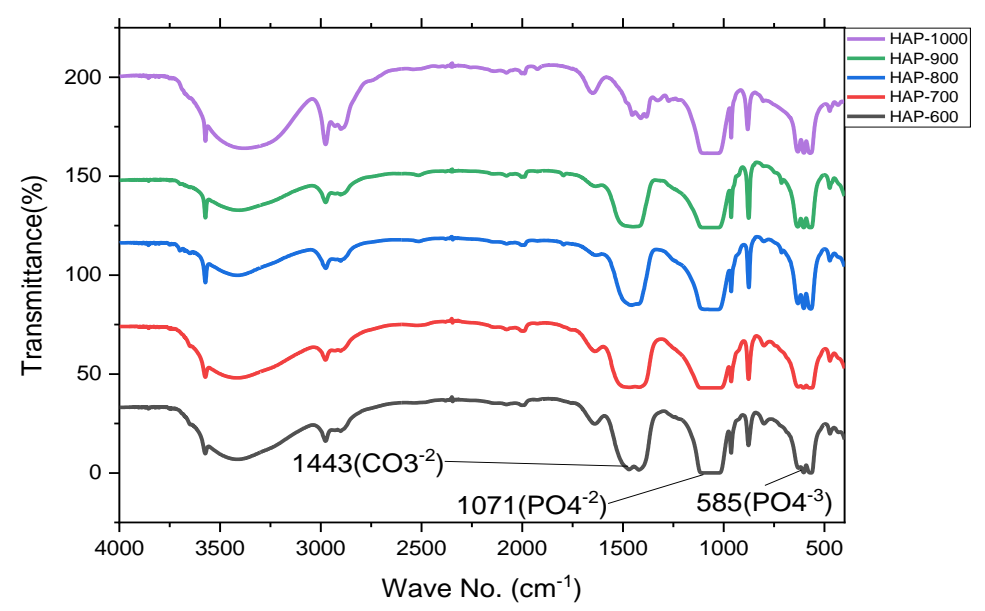

(b)

Figure 3. FTIR spectra of HAP (a)Uncalcined; (b) Calcined at $600,700,800,900$ and $1000{ }^{\circ} \mathrm{C}$.

Table 1. Infra-red vibration modes of various functional groups of synthesized HAP.

\begin{tabular}{c|c|c|c} 
Sr. No & Functional group & Vibrational Mode & Frequency $\left(\mathbf{c m}^{-\mathbf{1}}\right)$ \\
\hline 1 & $\mathrm{PO}_{4}^{-3}$ & bend $v_{4}$ & 568 \\
\hline 2 & $\mathrm{PO}_{4}^{-3}$ & bend $v_{4}$ & 604 \\
\hline 3 & $\mathrm{PO}_{4}^{-3}$ & bend $v_{3}$ & 1038 \\
\hline 4 & $\mathrm{CO}_{3}{ }^{-2}$ & group $v_{3}$ & 1421 \\
\hline 5 & $\mathrm{CO}_{2}$ & stretch $v_{3}$ & 2358 \\
\hline 6 & $\mathrm{H}_{2} 0$ adsorbed & bend $v_{2}$ & 1643 \\
\hline 7 & $\mathrm{OH}^{-}$ & structural $v_{\mathrm{s}}$ & 3425
\end{tabular}

\subsection{SEM analysis.}

Figure 4 presents the SEM micrographs for both calcined and uncalcined HAP powder. In SEM, irregular shapes, including small spheres, rods, and ovals, were seen, and somewhere agglomeration of particles was also observed. The same morphology has also been reported in previous literature [18-20]. The shapes of agglomerates look almost the same, having pores in 
between them. Pores' formation is extremely beneficial as they would permit the circulation of body fluids throughout the coating when HAP would be employed as a biomaterial.

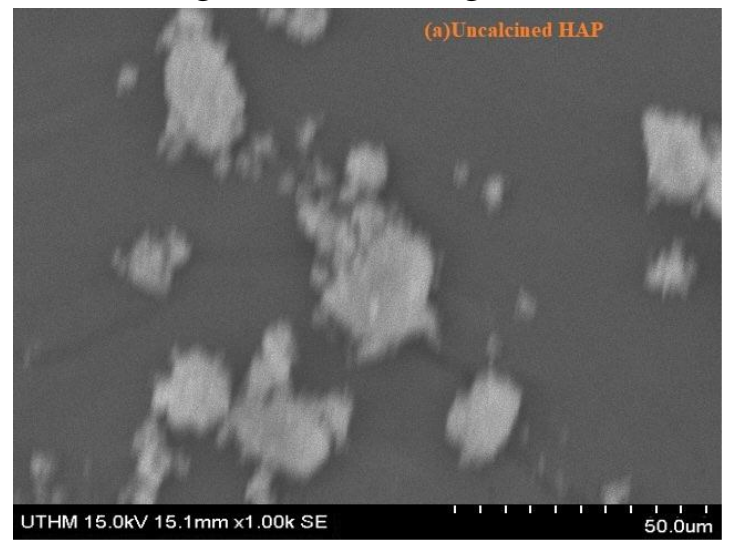

(a)

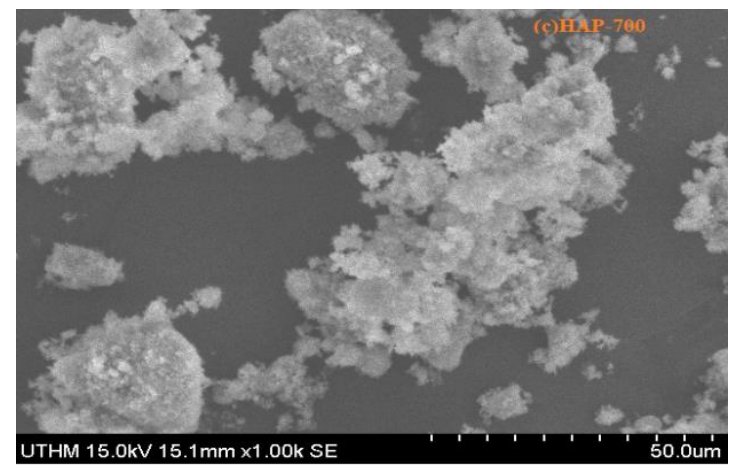

(c)

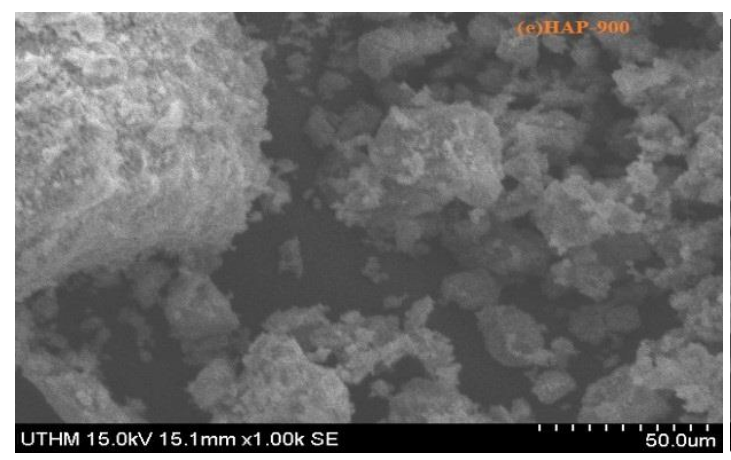

(e)

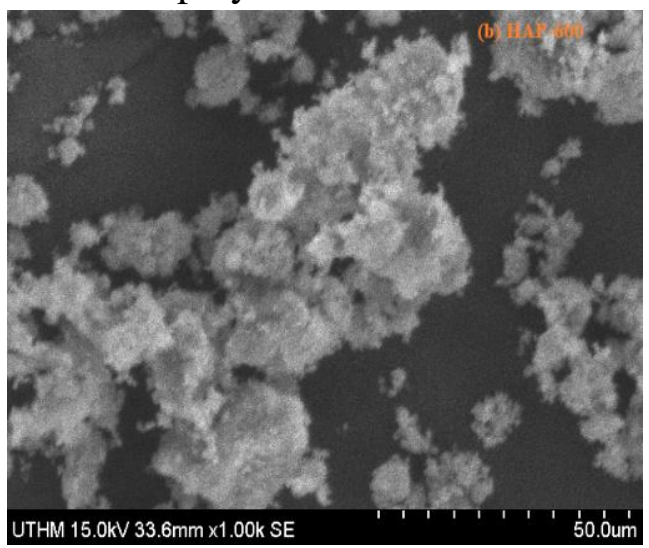

(b)

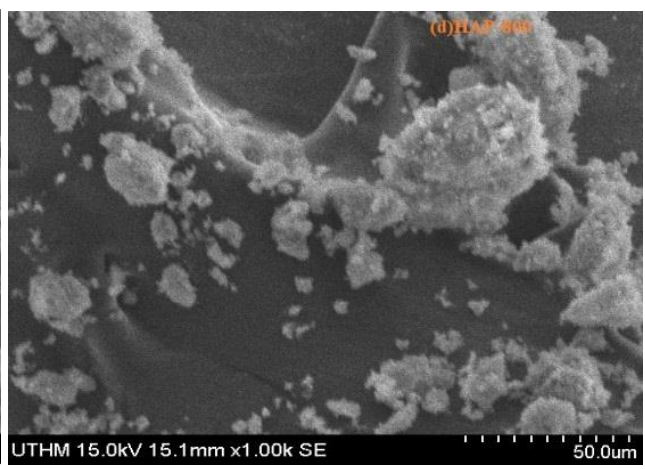

(d)

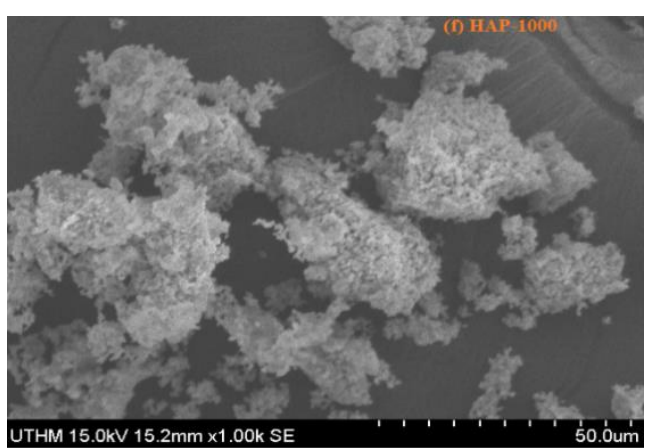

(f)

Figure 4. SEM for $\mathrm{HAP}(\mathbf{a})$ uncalcined and calcined at temperature (b) $600{ }^{\circ} \mathrm{C} ;(\mathbf{c}) 700^{\circ} \mathrm{C} ;(\mathbf{d}) 800{ }^{\circ} \mathrm{C}$; (e) $900{ }^{\circ} \mathrm{C}$; (f) $1000^{\circ} \mathrm{C}$.

\subsection{EDX analysis.}

EDX analysis of uncalcined and calcined HAP powder is shown in Figure 5. The presence of calcium, phosphorous, and oxygen validates the synthesis of HAP. The weight and atomic percentages of these elements are also shown in Figure 5 . The $\mathrm{Ca} / \mathrm{P}$ ratio is determined from the EDX data, and it comes out to be 1.64 for uncalcined HAP and 1.61 for HAP calcined at $600^{\circ} \mathrm{C}$, as shown in Table 2 . It has been observed that when calcination temperature is increased above $600^{\circ} \mathrm{C}$, the $\mathrm{Ca} / \mathrm{P}$ ratio drops down to 1.57 to 1.42 . In contrast, the $1000^{\circ} \mathrm{C}$ calcined powder shows the conversion of HAP to Tricalcium phosphate (TCP). 


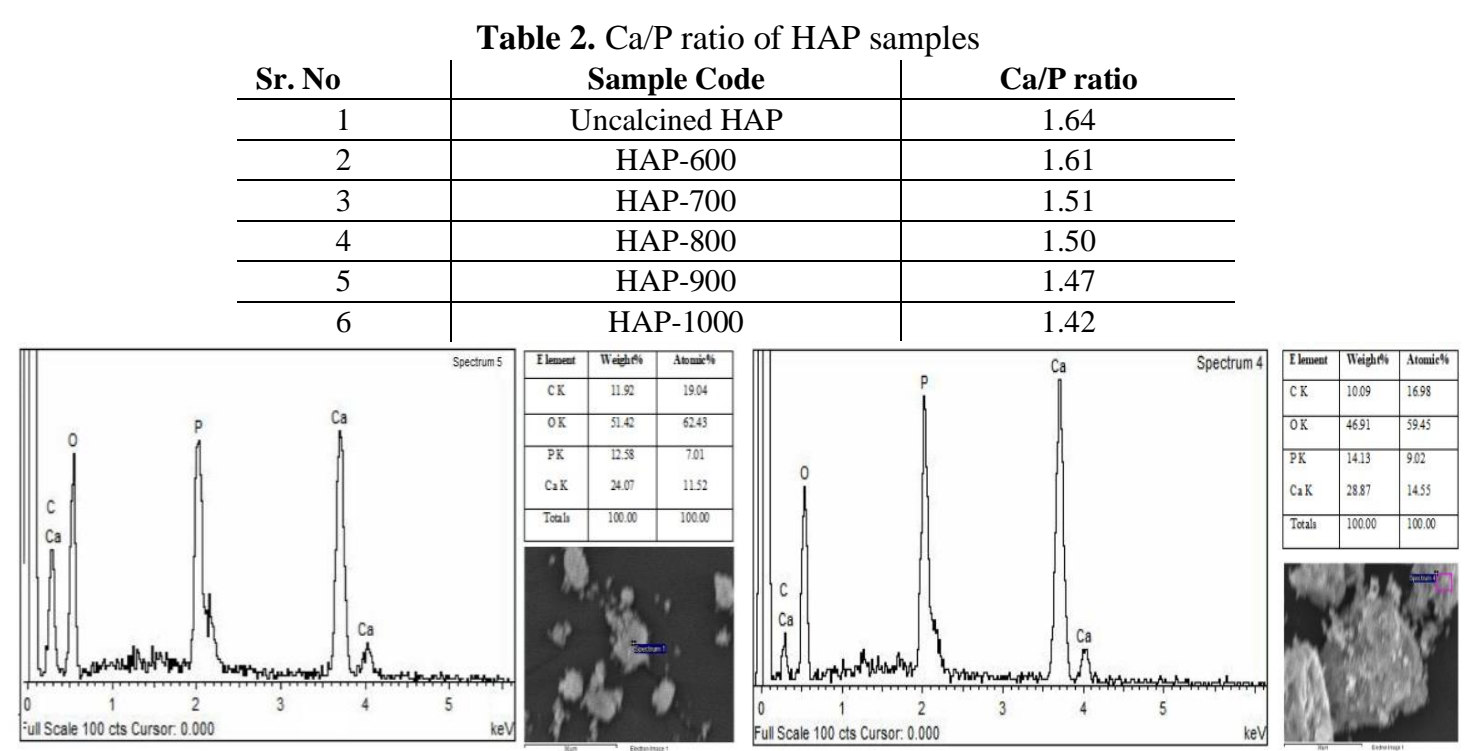

(a)

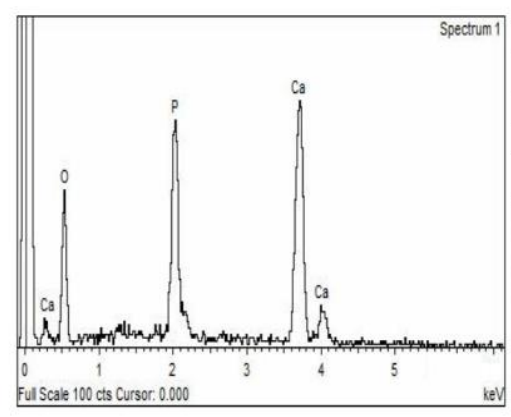

(c)

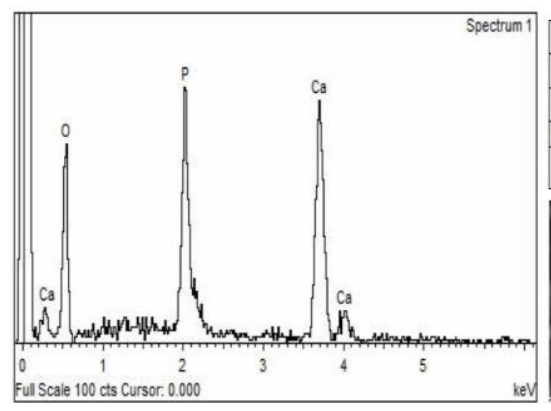

(e) (b)

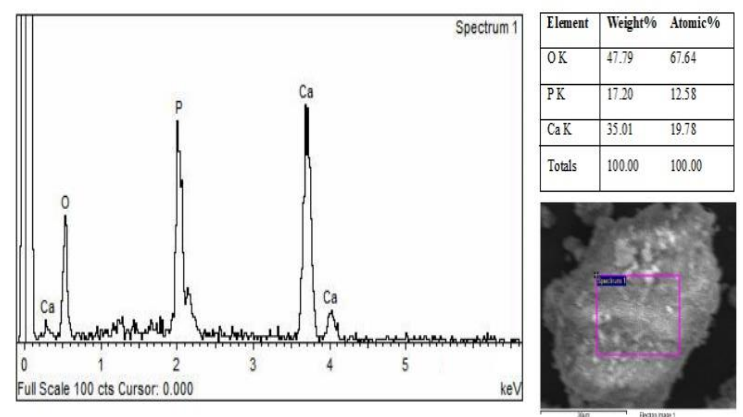

(d)

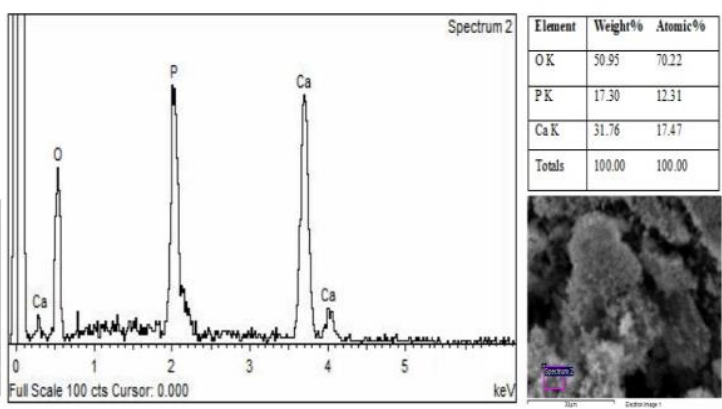

(f)

Figure 5. EDX analysis of synthesized HAP powder (a) Uncalcined and calcined at different temperature (b) HAP-600; (c) HAP-700; (d)HAP-800; (e) HAP-900; (f) HAP-1000.

\section{Conclusions}

The results obtained from all the characterization techniques confirm that HAP is synthesized from $\mathrm{CaO}$, employed as a precursor extracted from eggshell waste. The method used in the present study is the wet chemical precipitation method. It has high reproducibility, simplicity, and, most importantly, the economic benefits it offers on an industrial scale. The main advantages of the method include using eggshell waste as a precursor, being abundantly available and very cheap, and the only by-product generated during preparation is water which sanctions the method to be eco-friendly. The stoichiometric ratio for $\mathrm{Ca} / \mathrm{P}$ of 1.64 was obtained 
for uncalcined HAP nearest to the theoretical value of 1.67. The methodology for the extraction of HAP is simple, less time-consuming, and very low cost.

\section{Funding}

This research received no external funding.

\section{Acknowledgments}

The authors would like to express their deepest appreciation to all that have contributed to the success of this research, especially Universiti Tun Hussein Onn Malaysia for providing the laboratories facility to conduct this research.

\section{Conflicts of Interest}

The authors declare no conflict of interest.

\section{References}

1. Oliveira, É. R.; Nie, L.; Podstawczyk, D.; Allahbakhsh, A.; Ratnayake, J.; Brasil, D. L.; Shavandi, A. Advances in Growth Factor Delivery for Bone Tissue Engineering. Int. J. Mol. Sci. 2021, 22, 903-935, https://doi.org/10.3390/ijms22020903.

2. Lett, J. A; Sagadevan, S.; Fatimah, I.; Hoque, M. E.; Lokanathan, Y.; Léonard, E.; Alshahateet, S. F.; Schirhagl, R.; Oh, W. C. Recent advances in natural polymer-based hydroxyapatite scaffolds: properties and applications. Eur. Polym. J. 2021, 148, 110360, https://doi.org/10.1016/j.eurpolymj.2021.110360.

3. Montoya, C.; Du, Y.; Gianforcaro, A. L.; Orrego, S.; Yang, M.; Lelkes, P. I. On the road to smart biomaterials for bone research: definitions, concepts, advances, and outlook. Bone Res. 2021, 9, 1-16, https://doi.org/10.1038/s41413-020-00131-z.

4. Ghiasi, B.; Sefidbakht, Y.; Mozaffari-Jovin, S.; Gharehcheloo, B.; Mehrarya, M.; Khodadadi, A.; Rezaei, M.; Ranaei Siadat, S.O.; Uskoković, V. Hydroxyapatite as a biomaterial-a gift that keeps on giving. Drug Dev. Ind. Pharm. 2020, 46, 1035-1062, https://doi.org/10.1080/03639045.2020.1776321.

5. S, S.; S, R.; L, K.; Dhanaraj, G. Novel and naturally derived Hydroxyapatite/cellulose nanofibre/curcumin biocomposite for tissue engineering applications. Res.Sq 2021, 1, 1-20, https://doi.org/10.21203/rs.3.rs332070/v1.

6. Alorku, K.; Manoj, M.; Yuan, A. A plant-mediated synthesis of nanostructured hydroxyapatite for biomedical applications: A review. $R S C A d v$. 2020, 10, 40923-40939, https://doi.org/10.1039/d0ra08529d.

7. Nathanael, A. J.; Oh, T. H. Encapsulation of calcium phosphates on electrospun nanofibers for tissue engineering applications.Crystals 2021, 11, 199-221, https://doi.org/10.3390/cryst11020199.

8. Jaafar, A.; Hecker, C.; Árki, P.; Joseph, Y. Sol-gel derived hydroxyapatite coatings for titanium implants: a review. Bioengineering 2020, 7, 127-149, https://doi.org/10.3390/bioengineering7040127.

9. Wu, M.; Wu, P.; Xiao, L.; Zhao, Y.; Yan, F.; Liu, X.; Xie, Y.; Zhang, C.; Chen, Y.; Cai, L. Biomimetic mineralization of novel hydroxyethyl cellulose/soy protein isolate scaffolds promote bone regeneration in vitro and in vivo. Int. J. Biol. Macromol. 2020, 162, 1627-1641, https://doi.org/10.1016/j.ijbiomac.2020.08.029.

10. Veiga, A.; Castro, F.; Rocha, F.; Oliveira, A. L. Protein-based hydroxyapatite materials: tuning composition toward biomedical applications. ACS Appl. Bio Mater. 2020, 3, 3441-3455, https://doi.org/10.1021/acsabm.0c00140.

11. Sathiyavimal, S.; Vasantharaj, S.; LewisOscar, F.; Selvaraj, R.; Brindhadevi, K.; Pugazhendhi, A. Natural organic and inorganic-hydroxyapatite biopolymer composite for biomedical applications. Prog. Org. Coatings, 2020, 147, 105858, https://doi.org/10.1016/j.porgcoat.2020.105858.

12. Wei, G.; Gong, C.; Hu, K.; Wang, Y.; Zhang, Y. Biomimetic Hydroxyapatite on Graphene Supports for Biomedical Applications: A Review. Nanomaterials 2019, 9, 1435-1454, https://doi.org/10.3390/nano9101435. 
13. Errich, A; Azzaoui, K.; Mejdoubi, E.; Hammouti, B.; Abidi, N.; Akartasse, N.; Benidire, L.; Hajjaji, S. El.; Sabbahi, R.; Lamhamdi, A. Toxic heavy metals removal using a hydroxyapatite and hydroxyethyl cellulose modified with a new gum Arabic. Indones. J. Sci. Technol. 2021, 6, 41-64, https://doi.org/10.17509/ijost.v6i1.31480.

14. Predoi, D.; Iconaru, S.L.; Predoi, M.V.; Groza, A.; Gaiaschi, S.; Rokosz, K.; Raaen, S.; Negrila, C.C.; Prodan, A.-M.; Costescu, A.; Badea, M.L.; Chapon, P. Development of cerium-doped hydroxyapatite coatings with antimicrobial properties for biomedical applications. Coatings 2020, 10, 516-532, https://doi.org/10.3390/coatings10060516.

15. Bhandari, N.L.; Bista, S.; Gautam, T.R.; Bist, K.; Bhandari, G.; Subedi, S.; Dhakal, K.N.. An overview of synthesis based biomedical applications of Hydroxyapatite Nanomaterials. J. Nepal Chem. Soc. 2021, 42, 6474, https://doi.org/10.3126/jncs.v42i1.35333.

16. Baldassarre, F.; Altomare, A.; Corriero, N.; Mesto, E.; Lacalamita, M.; Bruno, G.; Sacchetti, A.; Dida, B.; Karaj, D.; Ventura, G.D.; Capitelli, F.; Siliqi, D. Crystal chemistry and luminescence properties of eu-doped polycrystalline hydroxyapatite synthesized by chemical precipitation at room temperature. Crystals 2020, 10, 250-265, https://doi.org/10.3390/cryst10040250.

17. Goh, K.W.; Wong, Y. H.; Ramesh, S.; Chandran, H.; Krishnasamy, S.; Sidhu, A.; Teng, W.D. Effect of pH on the properties of eggshell derived hydroxyapatite bioceramic synthesized by wet chemical method assisted by microwave irradiation. Ceram. 2021, 47, 8879-8887, https://doi.org/10.1016/j.ceramint.2020.12.009.

18. Bardhan, R.; Mahata, S.; Mondal, B. Processing of natural resourced hydroxyapatite from eggshell waste by wet precipitation method. Adv. Appl. Ceram. 2011, 110, 80-86, https://doi.org/10.1179/1743676110Y.0000000003.

19. Pandey, G.; Dhaka, K. N.; Singh, A. K.; Dhungel, S. K.; Adhikari, R. Facile methods of preparing pure hydroxyapatite nanoparticles in ordinary laboratories. Bibechana. 2021, 18, 83-90, https://doi.org/10.3126/bibechana.v18i1.29600.

20. Saeri, M.R.; Afshar, A.; Ghorbani, M.; Ehsani, N.; Sorrell, C.C. The wet precipitation process of hydroxyapatite. Mater. Lett. 2003, 57, 4064-4069, https://doi.org/10.1016/S0167-577X(03)00266-0.

21. Abidi, S.S.A.; Murtaza, Q. Synthesis and characterization of nano-hydroxyapatite powder using wet chemical precipitation reaction. J.Mater. Sci. Technol. 2013, 30, 307-310, https://doi.org/10.1016/j.jmst.2013.10.011.

22. Khandelwal, H.; Prakash, S. Synthesis and Characterization of Hydroxyapatite Powder by Eggshell, J. Miner. Mater. Charact. Eng. 2016, 04, 119-126, https://doi.org/10.4236/jmmce.2016.42011.

23. Chen, D.; Zhao, J.; Jiang, X. Synthesis and characterization of silver substituted strontium phosphate silicate apatite using solid-state reaction for osteoregenerative applications. Bioengineered. 2021, 12, 1111-1125, https://doi.org/10.1080/21655979.2021.1899670.

24. Sočo, E.; Papciak, D.; Michel, M.M.; Pająk, D.; Domoń, A.; Kupiec, B. Characterization of the physical, chemical, and adsorption properties of coal-fly-ash-hydroxyapatite composites. Minerals 2021, 11, 774-792, https://doi.org/10.3390/min11070774.

25. Cestari, F.; Agostinacchio, F.; Galotta, A.; Chemello, G.; Motta, A.; M. Sglavo, V. Nano-hydroxyapatite derived from biogenic and bioinspired calcium carbonates: synthesis and in vitro bioactivity. Nanomaterials 2021, 11, 264-277, https://doi.org/10.3390/nano11020264. 